\title{
Leaves from the Tree Poincianella pluviosa as a Renewable Source of Antiplasmodial Compounds against Chloroquine-Resistant Plasmodium falciparum
}

\author{
Jacqueline E. de Souza, ${ }^{a}$ Maria F. A. do Nascimento, ${ }^{b}$ Maria P. G. Borsodi, ${ }^{c}$ Ana P. de Almeida, ${ }^{d}$ \\ Bartira Rossi-Bergmann, ${ }^{c}$ Alaíde B. de Oliveira ${ }^{b}$ and Sônia S. Costa*a
}

anstituto de Pesquisas de Produtos Naturais, Universidade Federal do Rio de Janeiro, Av. Carlos Chagas Filho 373, Cidade Universitária, 21941-902 Rio de Janeiro-RJ, Brazil

${ }^{b}$ Faculdade de Farmácia, Universidade Federal de Minas Gerais, Av. Presidente Antonio Carlos 6627, Campus Pampulha, 31270-901 Belo Horizonte-MG, Brazil

'Instituto de Biofísica Carlos Chagas Filho, Universidade Federal do Rio de Janeiro, Av. Carlos Chagas Filho 373, Cidade Universitária, 21941-902 Rio de Janeiro-RJ, Brazil

${ }^{d}$ Universidade Severino Sombra (USS), Av. Expedicionário Oswaldo de Almeida Ramos 280, 27700-000 Vassouras-RJ, Brazil

\begin{abstract}
Poincianella pluviosa is a tree whose stem bark is reputed to have antidiarrheal, wound healing, antitumoral and antimalarial properties. Considering that the leaves of the tree are a more abundant and renewable source than the stem bark, we chose to study the antimalarial potential of this organ part. The aqueous leaf extract exhibited a rich phenolic profile. It was active $\left(\mathrm{IC}_{50}=6.88 \pm 1.64 \mu \mathrm{g} \mathrm{mL}-1\right)$ against chloroquine resistant Plasmodium falciparum (W2) without toxicity to HepG2 A16 cells. The organic fraction was more active $\left(\mathrm{IC}_{50}=1.83 \mu \mathrm{g} \mathrm{mL}^{-1}\right)$ than the aqueous leaf extract itself. Ten phenolic compounds were obtained from the latter. This is the first report on the phenolic composition of $P$. pluviosa leaves. Ellagic acid $\left(\mathrm{IC}_{50}=0.215 \pm 0.007 \mu \mathrm{g} \mathrm{mL}^{-1}\right)$ proved to be 32 fold more active than the aqueous leaf extract itself. Considering their renewable aspect, leaves of P. pluviosa appear to be a more interesting source of antimalarial compounds than stem bark.
\end{abstract}

Keywords: Poincianella pluviosa var. peltophoroides, leaves, ellagic acid, malaria, Plasmodium falciparum (W2)

\section{Introduction}

A reduction in the incidence of tropical diseases such as malaria in poor countries is considered a major goal of the international community. ${ }^{1,2}$ In 2013, malaria was reported to be a threat to 198 million people causing 584,000 deaths in the world, mostly children under 5 years old in Africa. The impact of this disease is a major risk with the growth of world's population, mainly in regions without access to health services. The lack of sufficient financial resources and public health capacities in poor endemic countries led to the use of inefficient medicines and/or protocols resulting in an increase of mortality rate and spread of parasite resistance. ${ }^{2,3}$

Malaria is an infectious disease caused by protozoa of the genus Plasmodium, which is transmitted by female

*e-mail: sscostabh@gmail.com
Anopheles sp. mosquitoes. Five species of Plasmodium are able to infect humans, Plasmodium falciparum being considered the most dangerous. ${ }^{4}$ Some clinical manifestations such as fever, chills, mild anemia and diarrheas are associated with malaria. ${ }^{3,5}$

According to World Health Organization (WHO)established protocols, ${ }^{2}$ the treatment of uncomplicated Plasmodium falciparum malaria involves artemisininbased combination therapy with drugs such as mefloquine, piperaquine or the sulfadoxine/pyrimethamine combination. Nowadays, antimalarial therapy in endemic regions is more difficult to manage since the parasite has become resistant to most antimalarial drugs. ${ }^{3,6}$ The resistance to artemisinin emerged in regions where this drug was used in a monotherapy protocol. ${ }^{2,7}$ This situation continuously stimulates the search for new antimalarial drugs, especially from natural sources. ${ }^{1}$ 
Plants showing proven antimalarial activity still represent a promising source of new medicines. It is important to note that some antimalarial drugs such as artemisinin and quinine have plant origin. ${ }^{1,6,8}$

Poincianella pluviosa (DC.) L. P. Queiroz (syn. Caesalpinia pluviosa DC., Caesalpinia peltophoroides Benth., Caesalpinia pluviosa var. peltophoroides (Benth.) G.P. Lewis) is a species belonging to the Fabaceae family. ${ }^{9}$ This tree is widely distributed in Bolivia and eastern Brazil. Some varieties of this species have already been described. Poincianella pluviosa var. peltophoroides, which was chosen for investigation in this study, occurs in various phytogeographic domains, mainly in the Atlantic Forest biome. ${ }^{10-12}$ This tree can reach up to $16 \mathrm{~m}$ in height. Due to its rapid growth and high number of viable seeds, this plant is used for reforestation of degraded areas as well as in urban landscaping. ${ }^{11,13}$ This ornamental tree is widespread in gardens and public spaces in Brazil. The stem bark from the tree presents antidiarrheal, wound healing and antimalarial therapeutic properties. ${ }^{14-16}$ More specifically, Tacana Indians living in the Amazonian Bolivian forest use decoction of the stem bark from P. pluviosa for diarrhea and dysentery. Phenolic compounds and terpenoids were reported in flowers and stem bark from P. pluviosa. ${ }^{16-18}$

Taking into account the medicinal aspects of $P$. pluviosa, this study aimed to evaluate the antimalarial potential of its leaves. Leaves were chosen because of the abundance of these plant organs and their renewable characteristics in comparison with stem bark whose over-collection can be a threat to the integrity of the species, possibly leading to its extinction. ${ }^{19-22}$ The unrestrained collection of the vegetal parts such as bark, for example, contributed to the extinction of economically important species such as Taxus brevifolia..$^{23}$ According to Chemat et al. ${ }^{19}$ this choice of a renewable resource also follows one of the principles of green chemistry applied to natural products. To our knowledge, the chemical composition and the biological activity of $P$. pluviosa leaves have scarcely been investigated. ${ }^{24}$ Therefore, the aim of this study was to evaluate both the antimalarial activity and the chemical composition of aqueous extracts from leaves of $P$. pluviosa.

\section{Experimental}

\section{General experimental procedures}

Nuclear magnetic resonance (NMR) spectra were acquired on Varian VNMRS-500 $\left({ }^{1} \mathrm{H}, 499.77 \mathrm{MHz} ;{ }^{13} \mathrm{C}\right.$, $125.68 \mathrm{MHz})$ and VNMRS-400 $\left({ }^{1} \mathrm{H}, 399.77 \mathrm{MHz} ;{ }^{13} \mathrm{C}\right.$, $100.68 \mathrm{MHz}$ ) spectrometers (LAMAR, IPPN, UFRJ, Brazil). Electrospray ionization (ESI) mass spectra (MS) were obtained using a BRUKER MicroTOF-II mass spectrometer (IPPN, UFRJ, Brazil). MS data were acquired in negative ionization mode. Melting points were measured in a Koffler apparatus (IPPN, UFRJ, Brazil). RP-2 silanized silica (70-230 mesh, Merck, Germany) and Sephadex LH-20 gel (100-250 nm, Sigma, Holland) were used for extract purification. Eluates were monitored by thin layer chromatography (TLC) on silica 60F254 (Merck, Germany) using 8:1:1 mixture of $n$-butanol/acetic acid/water (BAW). The spots were visualized under UV (254 and $365 \mathrm{~nm}$ ), followed by development with cerium sulfate, ferric chloride or natural products-polyethyleneglycol (NP-PEG) (methanolic diphenyl boryloxy ethylamine followed by ethanolic polyethylene glycol-4000) solutions. Commercial samples of gallic acid (purity: $97.9 \%$ ), ellagic acid (purity: $\geq 95 \%$ ) and protocatechuic acid (purity: $\geq 97 \%$ ) were purchased from Sigma-Aldrich (Germany). Methanol for high-performance liquid chromatography (HPLC) was from Tedia (Brazil).

\section{HPLC-DAD analyses}

HPLC analyses were performed using an Agilent 1200 Infinity Series liquid chromatograph equipped with a diode array detector (DAD, model 1260, G4212B) (IPPN, UFRJ, Brazil). A reversed-phase Kromasil C18 column ( $5 \mu \mathrm{m}$, $250 \mathrm{~mm}, 2.5 \mathrm{~mm}$ ) was used, and the gradient was water containing $0.01 \%$ formic acid (eluent A) and methanol (eluent B). Stock solutions of P1 and P2 extracts in 1:1 $\mathrm{H}_{2} \mathrm{O} / \mathrm{MeOH}\left(2.5 \mathrm{mg} \mathrm{mL}^{-1}\right)$ were sonicated (30 s) and filtered on a Millipore filter (Merck, Germany). Samples were run for $50 \mathrm{~min}$ at $1 \mathrm{~mL} \mathrm{m^{-1 }}$ and absorbance was monitored between 254 and $365 \mathrm{~nm}$, using the following gradient sequence: $0-10 \mathrm{~min}(100-90 \%$ A), $10-15 \min (90-80 \% \mathrm{~A}), 15-20 \min (80-70 \%$, A), 20-30 $\min (70-50 \% \mathrm{~A}), 30-40 \min (50-30 \% \mathrm{~A})$, 40-50 min (30-0\% A). An analytical calibration curve was elaborated using ellagic acid (Sigma-Aldrich, Germany, purity: $\geq 95 \%$ ) as a chemical standard at 0.15 , $0.30,0.6,1.2,2.4$ and $4.8 \mu \mathrm{g} \mathrm{mL}^{-1}$. The calibration curve $\left(y=20000000 x+10000000 ; R^{2}=0.9988\right)$ was used to quantify ellagic acid itself as well as its derivatives in the extract. The points of the curve were obtained from triplicate analyses. Valoneic acid dilactone was quantified using a correction factor (molecular mass of valoneic acid dilactone/molecular mass of ellagic acid).

\section{Plant samples}

Leaves from P. pluviosa var. peltophoroides were collected in Mendes, RJ, Brazil (-22॰31'34.6”S, 
4343'48.4”W). A voucher specimen (39960) was identified by Dr Luciano Paganucci Queiroz (Universidade Estadual de Feira de Santana (UEFS), Bahia, Brazil).

\section{Leaf extraction and isolation of compounds}

The first batch of leaves from P. pluviosa var. peltophoroides was harvested from one specimen out of flowering (batch P1; October 2009). Additional leaf material was obtained from the same specimen in its flowering period (batch P2; November 2010). Fresh leaves from both batches were blended and extracted separately by decoction $(15 \mathrm{~min})$ with distilled water $(10 \% \mathrm{~m} / \mathrm{v})$. The extracts were filtered, frozen and lyophilized.

\section{First leaf batch P1 (non-flowering period)}

Decoction of fresh leaves (P1; 527.7 g) afforded $51.5 \mathrm{~g}$ of lyophilized extract (P1-E). A sample of P1-E (30.0 g) was suspended in water $(120 \mathrm{~mL})$ and partitioned with ethyl acetate, affording $3.30 \mathrm{~g}$ of the ethyl acetate fraction (P1-A). A sample of P1-A ( $813.6 \mathrm{mg}$ ) was re-suspended in ethanol resulting in an insoluble fraction P1-A1 (101.3 mg) and a soluble fraction P1-A2 (712.3 mg). P1-A1 (58.9 mg) was solubilized in 2:1 MeOH/acetone and injected on Sephadex LH-20 (MeOH). This purification afforded $29.0 \mathrm{mg}$ of ellagic acid (1) and $12.1 \mathrm{mg}$ of valoneic acid dilactone (2). Ellagic acid (1): retention factor (Rf) 0.42 ; retention time $\left(t_{R}\right) 30.72$ min, purity $=91.8 \%$; NMR data according to Silva et al. ${ }^{25}$ HRMS (TOF (time-of-flight) + ESI) $\mathrm{m} / \mathrm{z}[\mathrm{M}-\mathrm{H}]^{-}:$301. Valoneic acid dilactone (2): Rf 0.32; $\mathrm{t}_{\mathrm{R}} 23.39 \mathrm{~min}$; NMR data according to Silva et al. ${ }^{25} \mathrm{HRMS}$ $(\mathrm{TOF}+\mathrm{ESI}) \mathrm{m} / \mathrm{z}[\mathrm{M}-\mathrm{H}]^{-}: 469$. An aliquot of P1-A2 (712.3 g) was chromatographed on a Sephadex LH-20 (EtOH/70\% EtOH) to give fractions P1-A2-1 (79.6 mg), P1-A2-2 (361.2 mg) and P1-A2-3 $(250 \mathrm{mg})$. A sample of P1-A2-2 (256.2 mg) was chromatographed on Sephadex LH-20 (EtOH) affording gallic acid (3; $113.9 \mathrm{mg})$ and protocatechuic acid $(4 ; 9.7 \mathrm{mg})$. Gallic acid (3): Rf 0.63; $\mathrm{t}_{\mathrm{R}} 8.43 \mathrm{~min}$; NMR data according to Moura et al.; ${ }^{26}$ HRMS (TOF + ESI) $\mathrm{m} / z[\mathrm{M}-\mathrm{H}]^{-}:$169. Protocatechuic acid (4): Rf 0.8; $\mathrm{t}_{\mathrm{R}} 13.4 \mathrm{~min}$; NMR data according to Moura et al.; ${ }^{26} \mathrm{HRMS}$ (TOF + ESI) $m / z[\mathrm{M}-\mathrm{H}]^{-}: 154$.

An aliquot of fraction P1-A2-3 (110 mg) was chromatographed on Sephadex LH-20 $\left(\mathrm{H}_{2} \mathrm{O} / \mathrm{MeOH}\right)$ to give $9.5 \mathrm{mg}$ of corilagin (5): $\mathrm{Rf} 0.68 ; \mathrm{t}_{\mathrm{R}} 22.55 \mathrm{~min}$; NMR data according to Colombo et al. ${ }^{27}$ HRMS (TOF + ESI) $\mathrm{m} / \mathrm{z}[\mathrm{M}-\mathrm{H}]^{-}:$633.0. Fraction P1-A2-3a $(33.5 \mathrm{mg})$ was chromatographed on Sephadex LH-20 $\left(\mathrm{H}_{2} \mathrm{O} / \mathrm{MeOH}\right)$, yielding $6.9 \mathrm{mg}$ of brevifolin carboxylic acid (6): $\mathrm{Rf} 0.32$; $\mathrm{t}_{\mathrm{R}} 22.00 \mathrm{~min}$; NMR data according to N'Guessan et al.;28 HRMS (TOF + ESI) $m / z$ [M - H] $]^{-} 291$.

\section{Second leaf batch P2 (flowering period)}

Fresh leaves (P2; $257.3 \mathrm{~g})$ were triturated and extracted by $10 \% \mathrm{~m} / \mathrm{v}$ decoction as mentioned above, affording $21.2 \mathrm{~g}$ of lyophilized extract (P2-E). An aliquot of P2-E $(8.3 \mathrm{~g})$ was re-suspended in water $(120 \mathrm{~mL})$ and partitioned with ethyl acetate. The acetate fraction P2-A $(0.98 \mathrm{~g})$ was re-suspended in ethanol, resulting in an insoluble fraction P2-A1 (83.3 mg) and a soluble fraction P2-A2 (893.5 mg). P2-A1 corresponded to ellagic acid (1). Part of P2-A2 (662.8 mg) was chromatographed on Sephadex LH-20 $\left(\mathrm{H}_{2} \mathrm{O} / \mathrm{EtOH}\right)$, affording P2-A2-1 (EtOH; $\left.21.6 \mathrm{mg}\right), \mathrm{P} 2-\mathrm{A} 2-2$ (EtOH; 239.7 mg), P2-A2-3 (EtOH; $103.2 \mathrm{mg}$ ), P2-A2-4 (70\% EtOH; $282.7 \mathrm{mg}$ ).

The purification of fraction P2-A2-2 (239.7 mg) on RP-2 $\left(\mathrm{H}_{2} \mathrm{O} / \mathrm{MeOH}\right)$ afforded $40.4 \mathrm{mg}$ of gallic acid (3; Rf 0.63), a $1: 1 \mathrm{mixture}(30.8 \mathrm{mg})$ of isoquercitrin (7): Rf 0.74 ; $\mathrm{t}_{\mathrm{R}} 29.90 \mathrm{~min}$; NMR data according to Al-Sayed et al. $;^{29}$ HRMS (TOF + ESI) $m / z[\mathrm{M}-\mathrm{H}]^{-}: 463$ and isovitexin (8): Rf 0.69; $\mathrm{t}_{\mathrm{R}} 29.64 \mathrm{~min}$; NMR data according to Peng et al.; 30 HRMS (TOF + ESI) $m / z[\mathrm{M}-\mathrm{H}]^{-}: 431$.

Fraction P2-A2-3 was re-suspended in water, giving a brown amorphous precipitate $(15.6 \mathrm{mg}$ ), which corresponded to an additional amount of ellagic acid (1). The watersoluble phase of P2-A2-3 (62 mg) was chromatographed on Sephadex LH-20 $\left(\mathrm{H}_{2} \mathrm{O} / \mathrm{MeOH}\right)$, and afforded a fraction $(10.2 \mathrm{mg})$ containing majoritarily quercetin3-O-(6-O-galloyl)- $\beta$-glucopyranoside (9): $\operatorname{Rf} 0.44$; $\mathrm{t}_{\mathrm{R}} 28.27 \mathrm{~min}$; NMR data according to Al-Sayed et al.;29 HRMS (TOF + ESI) $m / z[M-H]^{-:}: 615$. The minor compound was identified as kaempferol-3-O-(6-O-galloyl) $\beta$-glucopyranoside (10): Rf 0.54; $\mathrm{t}_{\mathrm{R}} 31.05 \mathrm{~min}$; NMR data according to Al-Sayed et al. ${ }^{29} \mathrm{HRMS}$ (TOF + ESI) $m / z[\mathrm{M}-\mathrm{H}]^{-}: 599$. NMR, MS, Rf, $\mathrm{t}_{\mathrm{R}}, \mathrm{UV}$ data are available at the Supplementary Information. Identification of gallic acid, ellagic acid and protocatechuic acid was also confirmed by co-chromatography with authentic samples (Sigma-Aldrich, Germany).

\section{Cytotoxicity assay (HepG2 A16 cell line)}

Cytotoxicity was evaluated using hepatoma cells (HepG2 A16 cell line, as reported by Varotti et al.). ${ }^{31}$ The cells were distributed in 96-well microtiter plates $\left(4 \times 10^{5}\right.$ cells per $100 \mu \mathrm{L}$ for microtiter plates), and incubated for $24 \mathrm{~h}$ at $37^{\circ} \mathrm{C}$ in a $\mathrm{CO}_{2}$ atmosphere. Then, $100 \mu \mathrm{L}$ of complete medium containing different amounts of extract (P1-E), fractions (P1-A and P1-Aq), phenolic compounds (ellagic acid, gallic acid and valoneic acid dilactone) and a positive control (chloroquine) were added. The culture plates were incubated for an additional $24 \mathrm{~h}$, then 3-(4,5-dimethylthiazol-2-yl)- 
2,5-diphenyltetrazolium bromide (MTT) was added $\left(28 \mu \mathrm{L}\right.$ well $\left.{ }^{-1}\right)$ to a final concentration of $2 \mathrm{mg} \mathrm{mL}^{-1}$ in RPMI 1640 medium. After $1.5 \mathrm{~h}$ of incubation with MTT, dimethyl sulfoxide (DMSO) $(130 \mu \mathrm{L})$ was added to each well. The cultures plates were read using a multifunctional RChisto-Tecan-Infinite M200 Pro spectrophotometer at $510 \mathrm{~nm}$. The $50 \%$ cytotoxic concentration $\left(\mathrm{CC}_{50}\right)$ was determined by comparison with cultured cells without added extract, fractions or phenolic compounds, considered as 100\% growth. Each sample (extract, fractions and phenolic compounds) was tested in triplicate at concentrations of 1, 10, 100 and $1000 \mu \mathrm{g} \mathrm{mL}^{-1}$.

\section{Cytotoxicity assay (mouse peritoneal macrophages)}

The cytotoxicity of ellagic acid was evaluated using peritoneal macrophages obtained from Balb/c mice, according to Bernucci et al..$^{32}$ Peritoneal macrophages $\left(2 \times 10^{6}\right.$ cells $\left.\mathrm{mL}^{-1}\right)$ were incubated with ellagic acid at different concentrations $\left(0.4,2,10,50\right.$ and $\left.100 \mu \mathrm{g} \mathrm{mL}^{-1}\right)$ in RPMI medium supplemented with $5 \%$ fetal bovine serum and incubated for $48 \mathrm{~h}$ at $37{ }^{\circ} \mathrm{C}, 5 \% \mathrm{CO}_{2}$. After incubation, the cytotoxic activity was assessed using resazurin $\left(0.125 \mathrm{mg} \mathrm{mL}^{-1}\right.$, Sigma-Aldrich ${ }^{\circledR}$, Germany) and the cells were cultured for an additional $4 \mathrm{~h}$ at $37^{\circ} \mathrm{C}$. The number of viable cells was measured by culture fluorescence at $555 \mathrm{~nm}$ (excitation wavelength) and $585 \mathrm{~nm}$ (emission wavelength) using a SpectraMax ${ }^{\circledR}$ M5 spectrophotometer. The results were plotted as the percentage of viable cells normalized to untreated cells. The $\mathrm{CC}_{50}$ value (concentration capable of achieving $50 \%$ cytotoxicity) was calculated by nonlinear regression analysis using Graph Pad Prism 5.0. ${ }^{33}$ The tests were performed in triplicate.

\section{Antimalarial evaluation}

Plasmodium falciparum chloroquine-resistant (W2) strain was used to evaluate in vitro antiplasmodial activity. The lactate dehydrogenase (LDH) assay was used as described by Makler et al..$^{34}$ Malaria-infected erythrocytes were plated at ca. $2 \%$ parasitaemia and $1 \%$ hematocrit in 96-well microtiter plates, exposed to different concentrations of the samples, and incubated for $48 \mathrm{~h}$ at $37^{\circ} \mathrm{C}$. Then, the microplates were frozen to promote red blood cell hemolysis and aliquots were transferred into 96-well microtiter plates, to which was added Malstat reagent $(100 \mu \mathrm{L})$ and nitroblue tetrazolium (NBT)/phenazine ethosulphate (PES) mixture $(25 \mu \mathrm{L})$. After incubation $(1 \mathrm{~h})$, the absorbance was measured at $540 \mathrm{~nm}$. Chloroquine was the positive control and a drugfree medium the negative one. Tests were made in triplicate.
The results were classified according to the following criteria: very active, $\mathrm{IC}_{50}<1 \mu \mathrm{g} \mathrm{mL} L^{-1}$; active, $\mathrm{IC}_{50}=1-15 \mu \mathrm{g} \mathrm{mL}^{-1}$; moderately active, $\mathrm{IC}_{50}=15-25 \mu \mathrm{g} \mathrm{mL} \mathrm{m}^{-1}$; weakly active, $\mathrm{IC}_{50}=25-50 \mu \mathrm{g} \mathrm{mL}-1$; inactive, $\mathrm{IC}_{50}>50 \mu \mathrm{g} \mathrm{mL}^{-1}$.

For statistical analysis, the data were analyzed using the Origin 8.0 program. ${ }^{35}$

\section{Results and Discussion}

\section{Chemical study}

Leaves of $P$. pluviosa were extracted with water in a preparation very similar to that used by Tacana Indians. In addition, water extraction follows the trends of green chemistry in the use of safe and non-toxic solvents. ${ }^{19,36}$ The decoction of leaves from both batches yielded ca. 9\% of lyophilized crude extract in each case (P1-E and P2-E). The HPLC-DAD phenolic profiles of P1-E (Figure 1) and P2-E (Figure S1, see Supplementary Information) extracts revealed the presence of several peaks in the range of 256-365 nm. P1-E showed 17 peaks, while P2-E only 13 peaks. Quantification of peak Q, the most abundant phenolic compound in leaf extracts, revealed ellagic acid amounting to 1.3 and $1.08 \%$ of the extract for P1 and P2 batches, respectively. Plant secondary metabolites can suffer quantitative and qualitative variations influenced by biotic and abiotic factors. ${ }^{37-40}$ Since in our study both batches of leaves (P1 and P2) were harvested in the spring season from the same plant specimen with an interval of one year, the factors that influenced the modification in the concentration of the phenolic substances in P1 and P2 leaf materials remain unclear. Both P1-E and P2-E extracts had their chemical composition investigated, but only P1-A fraction (11.3\% yield, Figure S2, see Supplementary Information) and its main compounds were biomonitored for their antimalarial activity and cytotoxicity.

The phenolic profile was determined by comparing retention times $\left(t_{R}\right)$ and $U V$ spectra data with those already reported; authentic compounds were also used when available (Table 1).

The very scarce reports on chemical composition of $P$. pluviosa encouraged us to isolate and identify the main phenolic compounds detected in both P1-E and P2-E extracts (Figure 2). Two phenolic acids $(\mathbf{3}, \mathbf{4})$, four flavonoids $(7,8,9,10)$ and four tannins $(1,2,5,6)$ were obtained. Compounds $\mathbf{1}, \mathbf{3}$ and $\mathbf{5}$ were previously identified in extracts of flowers and bark of P. pluviosa by ESI-MS/MS analyses. ${ }^{15}$ The presence of flavonoids 7, 8, 9 and 10 in Poincianella is reported here for the first time. Structures of the compounds isolated from the ethyl acetate fractions (P1-A and P2-A) are depicted in Figure 2. 


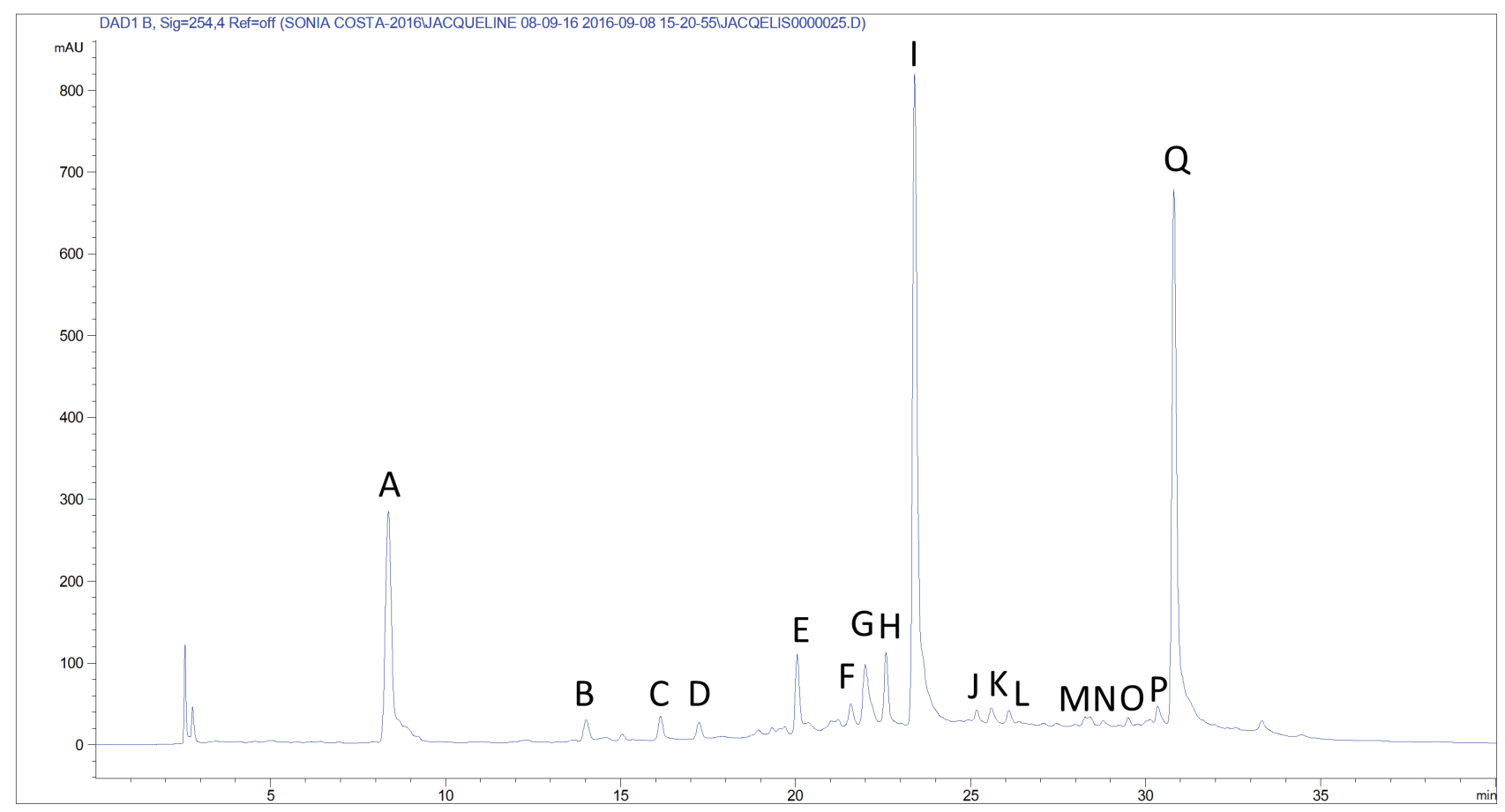

Figure 1. HPLC-DAD chromatogram of P1-E aqueous leaf extract $\left(2.5 \mathrm{mg} \mathrm{mL}^{-1} ; 254 \mathrm{~nm}\right.$; RP-18 column) from Poincianella pluviosa. Letters identify compounds listed in Table 1. Labels on x: mAu (milli absorption units); and y: min (minutes). For conditions, see Experimental section.

Table 1. Phenolic compounds in P1-E aqueous leaf extract from Poincianella pluviosa based on HPLC-DAD analysis

\begin{tabular}{lccc}
\hline Peak & Characterized compound & $\mathrm{t}_{\mathrm{R}} / \mathrm{min}$ & $\mathrm{UV} \lambda \max / \mathrm{nm}$ \\
\hline $\mathrm{A}$ & gallic acid (3) & 8.38 & 269 \\
$\mathrm{~B}$ & protocatechuic acid (4) & 14.01 & 292 \\
$\mathrm{C}$ & galloyl tannin & 15.32 & 269 \\
$\mathrm{D}$ & galloyl tannin & 17.24 & 269 \\
$\mathrm{E}$ & galloyl tannin & 20.04 & 269 \\
$\mathrm{~F}$ & ellagic acid derivative & 21.58 & 364 \\
$\mathrm{G}$ & brevifolin carboxylic acid (6) & 21.98 & 353 \\
$\mathrm{H}$ & corilagin (5) & 22.58 & 267 \\
$\mathrm{I}$ & valoneic acid dilactone (2) & 23.40 & 364 \\
$\mathrm{~J}$ & unidentified galloyl tannin & 25.17 & 270 \\
$\mathrm{~K}$ & ellagic acid derivative & 25.58 & 349 \\
$\mathrm{~L}$ & brevifolin derivative & 26.09 & 355 \\
$\mathrm{M}$ & quercetin-3-O-(6-O-galloyl) & 28.40 & 351 \\
& $\beta$-D-glucopyranoside (9) & & \\
$\mathrm{N}$ & ellagic acid derivative & 28.79 & 364 \\
$\mathrm{O}$ & isovitexin (8) & 29.50 & 331 \\
$\mathrm{P}$ & isoquercitrin (7) & 30.34 & 353 \\
$\mathrm{Q}$ & ellagic acid (1) & 30.80 & 367 \\
\hline
\end{tabular}

The shaded entries correspond to the three major compounds in P1-E extract. The assignment of substances was confirmed by co-injection of standards and substances isolated in the study. Numbers in bold correspond to structures shown in Figure 2. Compound $\mathbf{1 0}\left(t_{R} 31.05 \mathrm{~min}\right)$ was a very small peak, and for this reason it was not detectable in P1-E extract at the concentration applied for the $\operatorname{HPLC}\left(2.5 \mathrm{mg} \mathrm{mL}^{-1}\right)$. $\mathrm{t}_{\mathrm{R}}$ : retention time.

\section{Biological study}

The aqueous leaf extract (P1-E) of Poincianella pluviosa showed an in vitro inhibitory activity against chloroquine-resistant Plasmodium falciparum W2 $\left(\mathrm{IC}_{50}=6.88 \pm 1.64 \mu \mathrm{g} \mathrm{mL}-1\right)$ without toxicity at concentrations of 1, 10, 100 and $1000 \mu \mathrm{g} \mathrm{mL}^{-1}$ (Table 2).

In a previous study, Kayano et al. ${ }^{41}$ showed that a $50 \%$ ethanolic extract of stem bark of the same species was active $\left(\mathrm{IC}_{50}=4.84 \pm 0.17 \mu \mathrm{g} \mathrm{mL}^{-1}\right)$ against a chloroquineresistant Plasmodium falciparum (3D7) in an in vitro assay for $\left[{ }^{3} \mathrm{H}\right]$ hypoxanthine incorporation. Although slightly more active than the present leaf aqueous extract, the extract of stem bark and the corresponding fractions were highly toxic to MCF-7 cells at concentration of $100 \mu \mathrm{g} \mathrm{mL}{ }^{-1} .{ }^{41} \mathrm{In}$ an antimalarial assay using mice infected with Plasmodium chabaudi, the active fractions from stem bark extract killed $40 \%$ of the animals in doses of 75 and $50 \mathrm{mg} \mathrm{kg}^{-1}$ day $^{-1}$. The extraction of toxic substances could be related to the solvent employed for the stem bark extraction or the specific chemical composition of this plant organ. The antimalarial activity and absence of cytotoxicity to mammalian cells observed for the aqueous leaf extract in this study validate the use of this anatomical part of the plant.

Fractionation of $\mathrm{P} 1-\mathrm{E}$ was monitored by in vitro antimalarial assays. After partition, P1-Aq and P1-A fractions were both evaluated in the antimalarial assays. 
<smiles>O=c1oc2c(O)c(O)cc3c(=O)oc4c(O)c(O)cc1c4c23</smiles>

ellagic acid (1)<smiles>O=C(O)c1cc(O)c(O)c(O)c1Oc1cc2c(O)c3c4c(oc(=O)c5c(O)c(O)cc(O)c15)c(O)c(O)c(O)c4c2-3</smiles>

Valoneic acid dilactone (2)<smiles>O=C(O)c1cc(O)c(O)c(O)c1</smiles>

gallic acid (3)<smiles>O=C(O)c1ccc(O)c(O)c1</smiles>

protocatechuic acid (4)<smiles>O=C(O[C@H]1O[C@@H]2COC(=O)c3cc(O)c(O)c(O)c3-c3c(cc(O)c(O)c3O)C(=O)O[C@H]1[C@H](O)[C@H]2O)c1cc(O)c(O)c(O)c1</smiles><smiles>O=C1Cc2cc(O)c(O)c(O)c2C2=C1OCC2C(=O)O</smiles>

brevifolin carboxylic acid (6)<smiles>O=c1c(OC2OC3C(O)C(O)C(O)C(O)C3OC2O)c(-c2ccc(O)c(O)c2)oc2cc(O)cc(O)c12</smiles>
isoquercitrin (7)<smiles>O=C(OCC(OC(O)C(O)C(O)CO)C(O)CO)c1c(-c2ccc(O)c(O)c2)oc2cc(O)cc(O)c2c1=O</smiles><smiles></smiles>

isovitexin (8)<smiles>O=C(OCC(O)C(COC(=O)c1c(-c2ccc(O)cc2)oc2cc(O)cc(O)c2c1=O)OC(O)C(O)O)c1cc(O)c(O)c(O)c1</smiles>

quercetin-3-O-(6-O-galloyl)- $\beta$-D-glucopyranoside (9) kaempferol-3-O-(6-O-galloyl)- $\beta$-D-glucopyranoside (10)

Figure 2. Phenolic compounds identified from the ethyl acetate fractions (P1-A and P2-A) of aqueous leaf extracts from Poincianella pluviosa.

Table 2. Cytotoxicity and antimalarial activity of non-flowering Poincianella pluviosa leaf extract (P1), fractions (P1-A and P1-Aq) and the main phenolic compounds isolated

\begin{tabular}{lccc}
\hline Sample & $\begin{array}{c}\text { Cytotoxicity HepG2 }\left(\mathrm{CC}_{50}\right) / \\
\left(\mu \mathrm{gLL}^{-1}\right)\end{array}$ & $\begin{array}{c}\text { Antimalarial activity } \mathrm{IC}_{50} / \\
\left(\mu \mathrm{gL}^{-1}\right)\end{array}$ & $\begin{array}{c}\text { Classification of } \\
\text { malaria activity }^{\mathrm{a}}\end{array}$ \\
\hline Leaf extract (P1-E) & $>1000$ & $6.88 \pm 1.64$ & active \\
Acetate fraction (P1-A) & $>1000$ & 1.83 & active \\
Aqueous fraction (P1-Aq) & $>1000$ & $>50$ & inactive \\
Ellagic acid (1) & $>1000$ & $0.215 \pm 0.007$ & very active \\
Gallic acid (3) & $>1000$ & $25-50$ & weakly active \\
Valoneic acid dilactone (2) & $102.58 \pm 14.11$ & $25-50$ & weakly active \\
Chloroquine & $170.73 \pm 6.31$ & $0.137 \pm 9.37 \mathrm{ng} \mathrm{mL}^{-1}$ & very active \\
\hline
\end{tabular}

${ }^{a}$ See Experimental section for the classification scale. $\mathrm{CC}_{50}$ : concentration that reduce the viable cell count by $50 \%$; $\mathrm{IC}_{50}$ : concentration that caused $50 \%$ growth inhibition of Plasmodium falciparum. 
As shown in Table 2, P1-A fraction exhibited a higher activity $\left(\mathrm{IC}_{50}=1.83 \mu \mathrm{g} \mathrm{mL}^{-1}\right)$ when compared with the aqueous fraction, which can be considered inactive $\left(\mathrm{IC}_{50}>50 \mu \mathrm{g} \mathrm{mL}^{-1}\right)$. The increase of activity of the ethyl acetate fraction indicates an increase of the concentration in the bioactive substance(s), thus validating the pertinence of the partition step.

In a previous report, brevifolin carboxylic acid, corilagin and gallic acid exhibited moderate activity $\left(\mathrm{IC}_{50}>10 \mu \mathrm{g} \mathrm{mL}-1\right)$ against chloroquine-resistant Plasmodium falciparum (FcB1, FcM29, F32 and W2) strains in the $\left[{ }^{3} \mathrm{H}\right]$ hypoxanthine incorporation assay. Ellagic acid was reported as the most potent antiplasmodial compound among the phenolics tested..$^{42}$

Ellagic acid (1) and its derivatives have been found in several sources of plant kingdom. A wide range of biological activities has been reported for this compound, among them antimutagenic, anticarcinogenic, antioxidant and anti-inflammatory activities..$^{43}$ Ellagic acid (1) is considered an important bioactive compound in plants presenting antimalarial activity. ${ }^{44,45}$ However, there is a controversy about the activity of this molecule in different in vitro antimalarial studies. Reddy et $\mathrm{al} .{ }^{46} \mathrm{did}$ not observe any activity for ellagic acid in a p-LDH assay against Plasmodium falciparum (D6 and W2). However, some studies reported antimalarial activity for this phenolic compound at 0.1 and $0.17 \mu \mathrm{g} \mathrm{mL}^{-1}$ using the hypoxanthine incorporation assay. ${ }^{42,47}$

Based on the initial screening at 25 and $50 \mu \mathrm{g} \mathrm{mL}^{-1}$, the activity of the three major constituents of (P1-E) fraction, ellagic acid (1), gallic acid (3) and valoneic acid dilactone (2) isolated from P. pluviosa, was assessed in p-LDH assays against Plasmodium falciparum (W2).

Compound 1 showed a stronger activity $\left(\mathrm{IC}_{50}=0.215 \pm 0.007 \mu \mathrm{gLL}^{-1}\right)$ than compounds $\mathbf{2}$ and $\mathbf{3}$ $\left(\mathrm{IC}_{50}=25-50 \mu \mathrm{g} \mathrm{mL}^{-1}\right)$. Ellagic acid and other hydrolyzable tannins were evaluated in the same model and parasite strains as described by Reddy et al. ${ }^{46}$ Contrary to what was observed by these authors, who also employed a W2 strain, our results showed that ellagic acid (1) was active in the p-LDH assay. According to the literature, ellagic acid was tested in several cell lines to evaluate its cytotoxic potential such as primarily MRC5 (human diploid embryonic lung), KB (human epidermoid carcinoma) and Vero (African green monkey kidney), and had no cytotoxicity at $100 \mu \mathrm{M}$ concentration. ${ }^{45}$ Usually cytotoxicity assays for the screening of antimalarial agents employ cell lineages from liver, blood, kidney, skin and nerve cells. ${ }^{48}$ In order to evaluate the cytotoxic potential of ellagic acid in normal cells, it was tested in mouse peritoneal macrophages, presenting $\mathrm{CC}_{50}=9.0 \pm 0.1 \mu \mathrm{g} \mathrm{mL}^{-1}$ and selectivity index $(\mathrm{SI})=414.7$. Substances with SI below 2 are toxic, and for this reason are not good candidates for antimalarial drugs. ${ }^{48}$ The SI observed for ellagic acid in our study is within the range considered safe for an antimalarial drug candidate.

Kayano et al. ${ }^{41}$ have investigated the composition of the most active antimalarial fraction from P. pluviosa by means of MS/MS analysis. Based on the $\mathrm{m} / z 303$ ion in MS/MS spectral analysis of the active fraction, the authors proposed a quercetin isomer as the antiplasmodial compound. This molecular ion is also compatible with ellagic acid (1); however, this possibility was excluded by the authors. ${ }^{41}$ It seems plausible to suppose that ellagic acid may be responsible for the antimalarial activity of the bark as well, since this compound has already been detected in the bark extract. ${ }^{15}$

From a mechanistic point of view, several studies suggest that ellagic acid (1) inhibits important enzymes necessary for the development of Plasmodium, such as plasmepsin II, $\beta$-hematin or glutathione- $S$-transferase. ${ }^{45,49}$ Studies have shown that the inhibitory effect of ellagic acid on plasmepsin II was not the main mechanism. It is suggested that the inhibition of $\beta$-hematin formation should be conditioned by the ability of ellagic acid to form a $\pi-\pi$ complex, increasing its affinity for hematin monomers. ${ }^{49}$ Compound $\mathbf{1}$ was also claimed to act at trophozoite or schizonte stages in the parasite life cycle, ${ }^{43}$ including oxidative conditions as well as the inhibition of key enzymes involved in metabolism as potential targets for modulation of the antiplasmodial activity..$^{50,51}$

Valoneic acid dilactone (2) is derived from ellagic acid (1) by esterification of the $8-\mathrm{OH}$ by a gallic acid unit. The weak activity of compound 2 at $1.5(22 \%)$ and $0.75 \mu \mathrm{g} \mathrm{mL}^{-1}(20 \%)$ suggests that the galloyl substitution is not favorable for the antiplasmodial activity. At 1.5 and $0.75 \mu \mathrm{g} \mathrm{mL}^{-1}$ ellagic acid inhibition was 70 and $64 \%$, respectively. The very small amount of compound 2 was insufficient for calculating the $\mathrm{IC}_{50}$ value. Intact hydroxyl groups in ellagic acid seem to be an important prerequisite for the antimalarial activity. ${ }^{50,52}$

In mice infected with Plasmodium vinckei petteri, ellagic acid showed curative and prophylactic activity when administered intraperitoneally, and orally it showed little curative activity and no prophylactic activity. ${ }^{45}$ Other studies have reported the loss of antimalarial activity in vivo in the model of Swiss mice infected with Plasmodium berghei and Plasmodium vinckei petteri. ${ }^{42,52}$ The loss of activity has been associated with low bioavailability of ellagic acid, which is metabolized by the intestinal microbiota in urolithins. The reactions involved in the metabolization result in the loss of one of the lactones and a hydroxyl group of the structure..$^{53}$ 
The metabolite urolithin was tested in in vitro assays and was shown to be inactive in Plasmodium falciparum growth and plasmepsin assays. ${ }^{52}$ The results with urolithin reinforce what was previously observed for valoneic acid dilactone. The integrity of the hydroxyl group in the structure is an essential structural requirement.

Despite the low activity by oral administration, ellagic acid and plant extracts rich in ellagitannins are still considered as a potential source of antimalarial substances, especially when supported by ethnopharmacological evidence. ${ }^{42,52,54}$ The antimalarial potential of ellagic acid has already been explored in phytotherapeutic formulation for prophylaxis and treatment of malaria in India. Based on the Ayurvedic knowledge of the properties of the Punica granatum extract, the OMARIA (Orissa Malaria Research Indigenous Attempt, Orissa, India) preparation for the fight against malaria in rural areas of India was formulated. The OMARIA preparation is prepared with fruits of $P$. granatum, which are reputed for their composition rich in ellagic acid and elagitanines. ${ }^{54,55}$ In vivo animal tests have limitations such as metabolism and bioavailability that make a comparison with humans difficult. Additionally, in these assays the strains employed were not Plasmodium falciparum. ${ }^{42,52}$ Dell'Agli et al. ${ }^{52}$ suggested that ellagitannins present in the extract of Punica granatum might contribute more for the in vivo antimalarial activity than ellagic acid (1) itself, since ellagitannins could act as a pro-drug.

The presence of hydrolyzable tannins in leaves from P. pluviosa makes this part of the plant more interesting than the stem bark as a source of tannins, regarding the renewable aspect. Ellagitannins are major compounds in leaves, since the concentration of ellagic acid (1) and valoneic acid dilactone (2) in the leaf P1-E extract is 1.3 and $2.43 \%$, respectively.

In the present study, ellagic acid (1) proved to be the main antiplasmodial compound. However, the potential for therapeutic utilization of the aqueous extract from P. pluviosa and its components should take into account the in vivo effect. Thus, the ellagitannin valoneic acid dilactone (2) and other phenolic compounds, although showing only moderate activity, may contribute to an in vivo antiplasmodial activity.

\section{Conclusions}

Our findings show that the P1 and P2 extracts from Poincianella pluviosa differed in pattern and concentration of phenolic compounds. Ten phenolic compounds were obtained, with ellagic acid (1), gallic acid (3) and valoneic acid dilactone (2) as the three most abundant components of the P1 extract, in decreasing order. In vitro antimalarial assays have proved that ellagic acid is the main bioactive compound from the aqueous leaf extract. The aqueous leaf extract showed no cytotoxicity, in sharp contrast with the results already described in the literature for the stem bark extract of this plant. Although P. pluviosa is not at risk of extinction, demonstration of the antiplasmodial potential and identification of the bioactive substance in a different part of the plant than the bark contribute to the possibility of a more sustainable use of this species. In conclusion, we can affirm that our preliminary results obtained in the study of a P. pluviosa leaf extract are extremely relevant to further research regarding this plant's antimalarial potential.

\section{Supplementary Information}

Supplementary information (Figures S1, S2 and data spectral of compounds) is available free of charge at http://jbcs.sbq.org.br as PDF file.

\section{Acknowledgments}

The antimalarial assays were sponsored by FAPEMIG (APQ-01129-10, Brazil) and CNPq (PRONEX Rede Malária; Process No. 555655/2009-1, Brazil) to A. B. Oliveira. J. E. de Souza and M. F. A. Nascimento are grateful to CAPES (Brazil) for PhD fellowships. The authors thank Dr L. P. Queiroz (UEFS, Bahia, Brazil) for the plant identification, Livia M. Casanova for helping with figure improvement and Dr Martha Sorenson for language revision.

\section{References}

1. Slingsby, B. T.; Kurokawa, K.; Lancet 2013, 1, 184.

2. http://apps.who.int/iris/bitstream/10665/176712/6/ 9789248564994_por.pdf?ua=1\&ua=1, accessed in December 2017.

3. White, N. J.; J. Clin. Invest. 2004, 113, 1084.

4. Mouatcho, J. C.; Goldring, J. P. D.; J. Med. Microbiol. 2013, 10, 1491.

5. Sodeinde, O.; Adeyemo, A. A.; Gbadegesin, R. A.; Olaleye, B. O.; Ajayi-Obe, K. E.; Ademowo, O. G.; J. Diarrhoeal Dis. Res. 1996, 14, 269.

6. Wells, T. N. C.; Huijsduijnen, R. H.; Voorhis, W. C. V.; Nature 2015, 14, 424.

7. Ashley, E. A.; Dhorda, R. M.; Fairhurst, C.; Amaratunga, P. L.; Suon, S.; Sreng, S.; Andreson, J. M.; Sam, C.; Sopha, C.; Chuor, C. M.; Nguon, C.; Sovannaroth, S.; Pukrittayakamee, S.; Hien, T. T.; Thuy-Nhien, N. T.; Thanh, N. V.; Phu, N. H.; Htut, Y.; Han, K. T.; Aye, K. H.; Mohuolu, O. A.; Olaosebikan, 
R. R.; Folaranmi, O. O.; Mayxay, M.; Khanthavong, M.; Hongvanthong, B.; Newton, P. N.; Onyamboko, M. A.; Fanello, C. I.; Tshefu, A. K.; Mishra, N.; Valecha, N.; Phyo, A. P.; Nosten, F.; Yi, P.; Tripura, R.; Borrmann, S.; Bashraheil, M.; Peshu, J.; Faiz, M. A.; Ghose, A.; Hossain, M. A.; Sarnad, R.; Kwiatkowski, D. P.; Bozdech, Z.; Jeeyapant, A.; Cheah, P. Y.; Sakulthaew, T.; Chalk, J.; Intharabut, B.; Silamut, K.; Lee, S. J.; Vihokhern, B.; Kunasol, C.; Imwong, M.; Tanrning, J.; Taylor, W. J.; Yeung, S.; Woodrow, C. J.; Flegg, J. A.; Das, D.; Smith, J.; Venkatesan, M.; Plowe, C. V.; Stepniewska, K.; Guerin, P. J.; Dondorp, A. M.; Day, N. P.; White, N. J.; N. Engl. J. Med. 2014, $371,411$.

8. Schimidt, T. J.; Romantha, S. A.; Khalid, A. J.; Alves, T. M. A.; Biavatti, M. W.; Brun, R.; Costa, E. B. D.; Castro, S. L.; Ferreira, V. F.; Lacerda, M. V. G.; Lago, J. H. G.; Leon, L. L.; Lopes, N. P.; das Neves, A. R. C.; Niehues, M.; Ogungbe, I. V.; Pohlit, A. M.; Scott, M. T.; Setzer, W. N.; Soeiro, M. N. C.; Steindel, M.; Tempone, A. G.; Curr. Med. Chem. 2012, 19, 2176.

9. http://www.tropicos.org/Name/100383047, accessed in August 2017.

10. de Queiroz, L. P.; Neodiversity 2010, 5, 11.

11. Lorenzi, H.; Árvores Brasileiras: Manual de Identificação e Cultivo de Plantas Arbóreas Nativas do Brasil; Plantarum: Nova Odessa, 1992.

12. http://floradobrasil.jbrj.gov.br/jabot/floradobrasil/FB109814, accessed in March 2017.

13. Miranda, C. Y.; Machado, M. S.; Silva, L. S.; Estevam, R.; Neto, F. F. M.; Caxambu, M. G.; REVSBAU 2015, 10, 71.

14. Bourdy, G.; Dewalt, S. J.; Cha, L. R.; J. Ethnopharmacol. 2000 , $70,87$.

15. Bueno, F. G.; Panizzon, G. P.; Mello, E. V. S. L.; Lechtenberg, M.; Petereit, F.; de Mello, J. C. M.; Hensel, A.; Fitoterapia 2014, 99, 252.

16. Bueno, F. G.; Moreira, E. A.; de Morais, G. R.; Pacheco, A. I.; Baesso, M. L.; Leite-Mello, E. V. S.; de Mello, J. C. P.; PloS One 2016, 3, 1.

17. Daniel, J. S. F.; Carvalho, M. G.; Ferreira, D. T.; Schimitz, W.; Saridakis, H. O.; Rev. Latinoam. Quim. 2004, 32, 25.

18. Flores, Y.; Vila, J.; Almanza, G. R.; Rev. Boliv. Quim. 2006, 23, 1.

19. Chemat, F.; Vian, M. A.; Cravotto, G.; Int. J. Mol. Sci. 2012, 13,8615 .

20. Williams, V. L.; Balkwill, K.; Witkowski, E. T. F.; Econ. Bot. 2000, 54, 310.

21. Feitosa, I. S.; Albuquerque, U. P.; Monteiro, J. M.; J. Ethnobiol. Ethnomed. 2014, 10, 1.

22. Cunningham, A. B.; People and Plants Working Paper; UNESCO: Paris, France, 1993.

23. Huxtable, R. J.; J. Ethnopharmacol. 1992, 37, 1.

24. Mendes, N. M.; Pereira, J. P.; de Souza, C. P.; de Oliveira, M. L. L.; Rev. Saude Publica 1984, 18, 348.
25. Silva, R. H.; da Silva, C. C.; Neto, C. C.; Lopes, J. A. D.; Citó, A. M. D. G. L.; Chaves, M. H.; Quim. Nova 2007, 30, 1877.

26. Moura, A. C. S.; Vilegas, W.; dos Santos, L. C.; Quim. Nova 2011, 34, 1136.

27. Colombo, R.; Batista, A. N. L.; Teles, H. L.; Silva, G. H.; Bonfim, G. C. C.; Burgos, R. C. R.; Cavalheiro, A. J.; Bolzani, V. S.; Silva, D. H. S.; Pelicia, C. R.; Guimarães, F. M.; Heimberg, M. C. H.; Biomed. Chromatogr. 2009, 23, 573.

28. N'Guessan, J. D.; Bidié, A. P.; Lenta, B. N.; Weniger, B.; André, P.; Guédé-Guina, F.; Afr. J. Biotechnol. 2007, 6, 1685.

29. Al-Sayed, E.; Tolba, M. F.; Karonen, M.; Rec. Nat. Prod. 2016, $10,812$.

30. Peng, J.; Fan, G.; Hong, Z.; Chai, Y.; Wu, Y.; J. Chromatogr. A 2005, 1074, 111.

31. Varotti, F. P.; Botelho, A. C.; Andrade, A. A.; de Paula, R. C.; Fagundes, E. M. S.; Valverde, A.; Mayer, L. M. U.; Medonça, J. S.; Souza, M. V. N.; Boechat, N.; Krettli, A. U.; Antimicrob. Agents Chemother. 2008, 52, 3868.

32. Bernuci, K. Z.; Iwanaga, C. C.; Fernandez-Andrade, C. M. M.; Lorenzetti, F. B.; Torres-Santos, E. C.; Faiões, V. S.; Gonçalves, J. E.; do Amaral, W.; Deschamps, C.; Scodro, R. B. L.; Cardoso, R. F.; Baldin, V. P.; Cortez, D. A. G.; Molecules 2016, 21, 1698.

33. Radushev, D.; GraphPad Prism 5.0, GraphPad Software, Inc., San Diego, CA, USA, 1992.

34. Makler, M. T.; Ries, J. M.; Willians, J. A.; Bancroft, J. E.; Piper, R. C.; Gibbins, B. L.; Hinrichs, D. J.; Am. J. Trop. Med. Hyg. 1993, 48, 739 .

35. Magallon, M. E.; Origin 8.0, OriginLab Corporation, Northampton, MA, USA, 2008.

36. Benzeggouta, N.; Ghanemi, A.; MOJ Public Health 2015, 3, 1.

37. Brasileiro, B. G.; Leite, J. P. V.; Casali, V. W. D.; Pizziolo, V. R.; Coelho, O. G. L.; Acta Sci., Agron. 2015, 37, 249.

38. Gobbo-Neto, L.; Lopes, N. P.; Quim. Nova 2017, 30, 374.

39. Oleyede, O. M.; Oleyede, F. A.; Obuotor, E. M.; Bull. Environ., Pharmacol. Life Sci. 2013, 2, 18.

40. Ramakrishna, A.; Ravishankar, G. A.; Plant Signaling Behav. 2011, 6, 1720.

41. Kayano, A. C.; Lopes, S. C.; Bueno, F. G.; Cabral, E. C.; SouzaNeiras, W. C.; Yamauchi, L. M.; Foglio, M. A.; Eberlin, M. N.; Mello, J. C.; Costa, F. T.; Malar. J. 2011, 2, 112.

42. Garcia-Alvarez, M. C.; Moussa, I.; Soh, P. N.; Nongonierma, R.; Abdoulaye, A.; Nicolau-Travers, M. L.; Fabre, A.; WdzieczakBakala, J.; Ahond, A.; Poupat, C.; Ikhiri, K.; Benoit-Vical, F.; J. Ethnopharmacol. 2013, 149, 676.

43. Vattem, D. A.; Shetty, K.; J. Food Biochem. 2005, 29, 234.

44. Ndjonka, D.; Bergmann, B.; Agyare, C.; Zimbres, F. M.; Lüersen, K.; Hensel, A.; Liebau, E.; Parasitol. Res. 2012, 111, 827.

45. Soh, P. N.; Witkowski, B.; Olagnier, D.; Nicolau, M. L.; GarciaAlvarez, M. C.; Berry, A.; Benoit-Vital, F.; Antimicrob. Agents Chemother. 2009, 53, 1100. 
46. Reddy, M. K.; Gupta, S. K.; Jacob, M. R.; Khan, S. I.; Ferreira, D.; Planta Med. 2007, 73, 461.

47. Verotta, L.; Dell'Agli, M.; Giolito, A.; Guerrine, M.; Cabalion, P.; Bosisio, E.; J. Nat. Prod. 2001, 64, 603.

48. Nogueira, F.; Rosário, V. E.; Rev. Pan-Amaz. Saude 2010, 3, 109.

49. Dell'Agli, M.; Parapini, S.; Basilico, N.; Verotta, L.; Taramelli, D.; Berry, C.; Bosisio, E.; Planta Med. 2002, 69, 162.

50. Simões-Pires, C.; Vargas, S.; Marston, A.; Ioset, J. R.; Paulo, M. Q.; Matheussen, A.; Maes, I.; Nat. Prod. Commun. 2009, 4, 1371.

51. Soh, P. N.; Witkowski, B.; Gales, A.; Huyghe, E.; Berry, A.; Pipy, B.; PLoS One 2012, 7, 5.
52. Dell'Agli, M.; Galli, G. V.; Corbett, Y.; Taramelli, D.; Lucantoni, L.; Habluetzel, A.; Maschi, O.; Caruso, D.; Giavarini, F.; Romeo, S.; Bhattacharya, D.; Bosisio, E.; J. Ethnopharmacol. 2009, 125, 279.

53. Espín, J. C.; Larrosa, M.; Garcia-Conesa, M. T.; TomásBarberán, F.; J. Evidence-Based Complementary Altern. Med. 2013, 2013, 15.

54. Lekana-Douki, J. B.; Bhattacharya, D.; Zatra, R.; Toure-Ndouo, F. S.; Int. J. Clin. Med. 2011, 3, 8.

55. Bhattacharya, D.; Asian Pac. J. Trop. Dis. 2011, 1, 142.

Submitted: May 30, 2017

Published online: December 12, 2017 